\title{
Penile Vascular System of the Dog. An Injection-Corrosion and Histological Study
}

\author{
Hiroyoshi NINOMIYA, Tsunenori NAKAMURA, Isao NIIZUMA ${ }^{1)}$, and Tokio TSUCHIYA ${ }^{2)}$ \\ Department of Laboratory Animal Science and ${ }^{2)}$ Department of Environmental Pathology, Azabu University, \\ Fuchinobe, Sagamihara, Kanagawa 229, ')Practitioner, 2-33-15 Kamishakuji Nerima, Tokyo 177, Japan
}

(Received 25 August 1988/Accepted 6 May 1989)

\begin{abstract}
The vascular architecture of the dog penis was studied by resin casts and histological preparations. Morphological evidence was found for penile engorgement. The crus and the bulb were compressed by the ischiocavernosus and the bulbospongiosus muscles, respectively, indicating that these muscles act as a booster pump. The distal part of the bulb was also strangulated by the external anal sphincter, indicating that this muscle prevents blood in the corpus spongiosum penis from going back into the bulb. The common trunk of the dorsal vein of the penis was significantly occluded by the ischiourethralis muscle. The internal pudendal vein was also throttled by the levator ani, the coccygeus, and the internal obturator muscles. The extremely narrow diameter of each vein draining the erectile body was insufficient to drain the increased blood flow and, therefore, formed a sluice channel. It is inferred that these muscle activities and sluice channels facilitate the erection of the penis.-KEY WORDS: dog, penile muscles, penis, resin casts, vasculature.
\end{abstract}

The vascular architecture of the dog penis has been studied considerably in detail by many investigators $[6,8,18,19,20,23,24]$, still with meager understanding which has led to a great deal of controversy as to the mechanism of penile engorgement. Henderson and Roepke [15] proposed that constriction of penile veins takes place in response to a neurogenic stimulus for erection. Christensen [6] suggested that mechanical compression of the venous drainage results from the contraction of the ischiourethralis (IU) and the bulbospongiosus (BS) muscles. Further, he believed that a shunting activity of double veins through the bulbus glandis (BG) is responsible for the delayed erection. Hart $[13,14]$ suggested that the erection mechanism results from strangulation of the common trunk of the dorsal vein of the penis by the IU muscle and from the pumping activity of the BS muscle to compress the bulb of the penis. Grandage [12] insisted that occlusion of the venous return by the turn and tail-to-tail position during coitus is responsible for the engorgement of the penis. Dorr and Brody [9] suggested that erection is due to an exceptionally increased blood inflow into the penis in a unit time instead of obstruction of venous drainage.

The present study was undertaken to re-investigate the vascular architecture of the dog penis and to assess the penile muscle activities by observation of casts made up of acrylic resin injected intraarterially into the penis just after exsanguination of the animal. The injected resin elicited tonic contraction of the extrinsic penile and perineal muscles. Thus, the obtained resin casts can be expected to make it possible to explain the cavernous body engorgement morphologically by such muscular contractile activities.

\section{MATERIALS AND METHODS}

Twenty adult mongrel dogs were used. Each animal was anesthetized by intravenous injection of sodium pentobarbital 


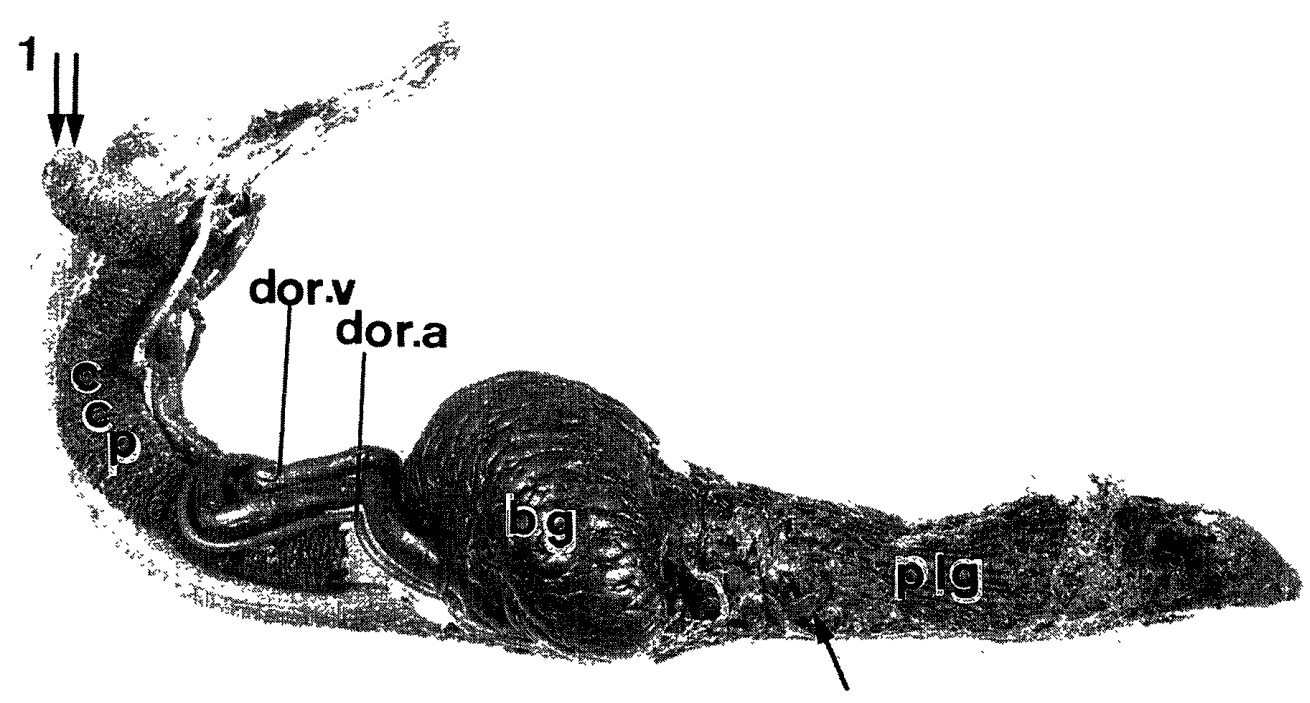

Fig. 1. Resin cast of the dog penis. Note the well-developed glans penis and arrangement of the cavernous spaces of each erectile body. Note compression by the ischiocavernosus muscle (double arrow 1) and Christensen's deep vein of the glans which connects the pars longa glandis (plg) and bulbus glandis (bg) (arrow). dor. a. v.; dorsal artery and vein of the penis. ccp; corpus cavernosum penis. csp; corpus spongiosum penis (lateral view). $\times 1.0$.

$(25 \mathrm{mg} / \mathrm{kg})$ and exsanguinated. To make the corrosion cast, methacrylic methylester monomer was supplemented with $1 \%$ benzoyl peroxide, $15 \%$ dibuthylphthalate and $0.5 \%$ chromophtal red, held at $60^{\circ} \mathrm{C}$ for $1 \mathrm{hr}$ for preliminary polymerization, and added with $1 \%$ dimethylaniline and additional $1 \%$ benzoyl peroxide just before injection. The resin was injected within 5 min after exsanguination. The injection was continued until the penis was thoroughly filled with the resin to show the maximum state of erection. After the plastic medium was polymerized, the specimens were immersed in $20 \%$ sodium hydroxide, washed in running water, and then dried. Four additional dogs were frozen and thawed to eliminate muscle contraction, and were given similar resin injection to make control casts.

For gross dissection, 3 additional dogs were embalmed with $10 \%$ formalin and later, given injection of red neoprene latex. For histological study, another 4 dogs were perfused with buffered $10 \%$ formalin in order to supplement the results obtained by the resin casts. Blocks of the vessels at the penile root and cavernous bodies were embedded in paraffin, cut serially, and stained with hematoxyline and eosin or by elastica Van Gieson's method.

\section{RESULTS}

The cavernous system: The overall appearance of the cavernous system is shown in figure 1.

The corpus cavernosum penis (CCP) was not well developed, occupying only a small part of the penis. The crus, to which the ischiocavernosus (IC) muscle was inserted, was compressed against the ischial tuberosity by the contraction of this muscle (Fig. 1). In the frozen and thawed specimens, however, such a contraction feature was not observed. The cavernous spaces of the bodies were small and narrow, arranged in a transversal direction to the long axis.

The corpus spongiosum penis (CSP) 


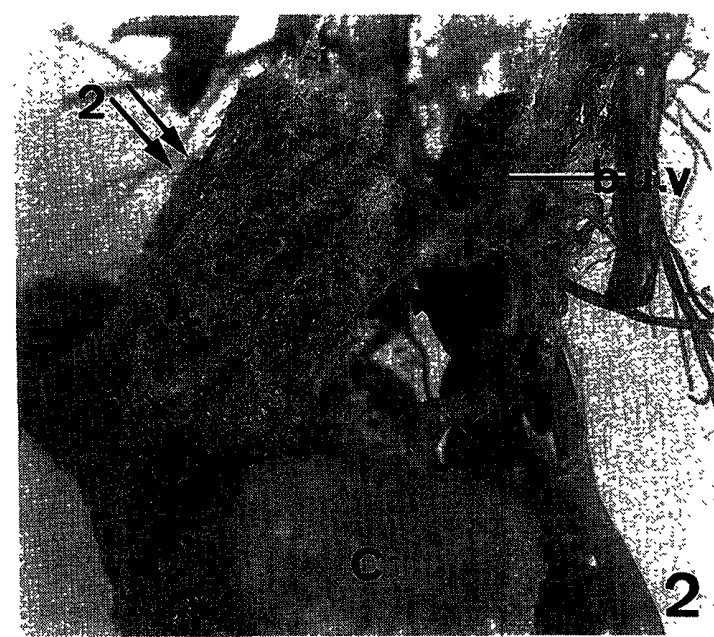

Fig. 2. The bulb with configurations of contraction of the bulbospongiosus muscle (double arrow 2, see also fig. 5) and that of the external anal sphincter muscle (double arrow 3). The vein of the bulb (bu. v) with an extermely narrow emergence, a sluice channel, from the corpus spongiosum penis is clearly shown (black arrow 3 ). c; crus. (lateral view). $\times 1.5$.

started as a bilobed expansion called the bulb. The bulb was compressed against the pelvic symphysis by the contraction of the BS muscle (Figs. 2, 5). Furthermore, the attachment of the external anal sphincter (EAS) muscle, which was a band of aponeurosis, was compressed to form a groove obliquely traversing the surface of the bulb. The cavernous spaces at this site were squeezed by the contraction of the EAS muscle (Fig. 2). In the frozen and thawed penis, such contraction figures were not observed. The body of the CSP was cylindrical. The cavernous spaces of the body were arranged longitudinally, surrounding the penile urethra. The cavernous body gave off many venous branches to the glans at its distal half (Fig. 3).

The glans is extremely well developed, comprising a major part of the penis (Fig. 1). It consists of the pars longa glandis (PLG) and the bulbus glandis (BG). The cavernous spaces of the PLG merged into 2 drainage channels at the proximal end; one continued to the superficial vein of the glans

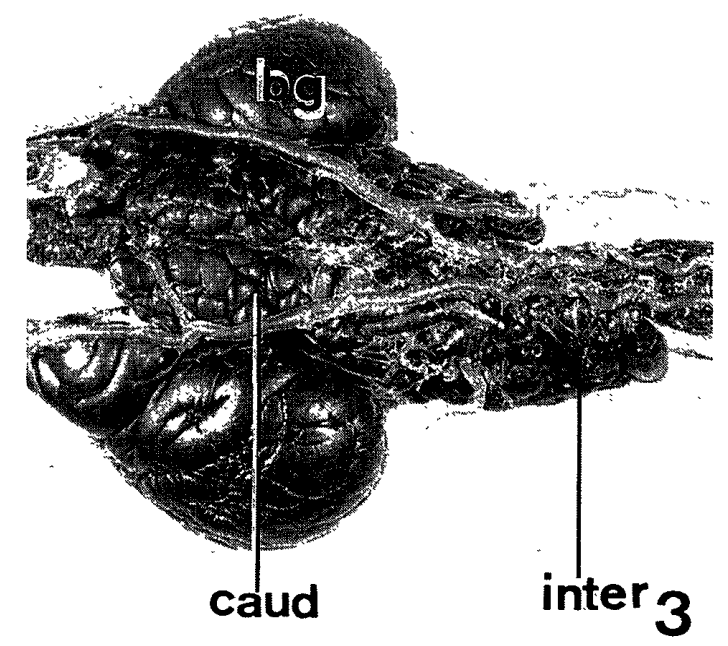

Fig. 3. The bulbus glandis (bg) with the caudal (caud) and the intermediate (inter) shunts which connect the corpus spongiosum penis and the organ. (ventral view). $\times 1.5$.

(Fig. 6) and the other drained blood into the craniolateral portion of the BG (Fig. 1). The latter was the only vein which connected the PLG with the BG as Nitschke [20] reported. It may correspond to Christensen's deep vein. A few valves were present in this vein to direct blood from the PLG to the BG. The cavernous spaces of the BG were larger in diameter than those of other erectile bodies. Any double connection between the deep vein and the dorsal vein in the body as described by Christensen [6] was not observed.

Arteries: The artery of the penis gave rise to the artery of the bulb before giving off the deep artery and the dorsal artery of the penis at the point short of the penile root (Fig. 4).

The artery of the bulb was large enough in diameter to supply a large amount of blood required for erection, and was divided into 2 or 3 branches just before entering the CSP. The main branch ran distally for a short course on the dorsomedial portion of the bulb to enter the CSP. Another branch entered the bulb immediately after originating from the parent vessel. These 2 main branches ramified into many arterioles 


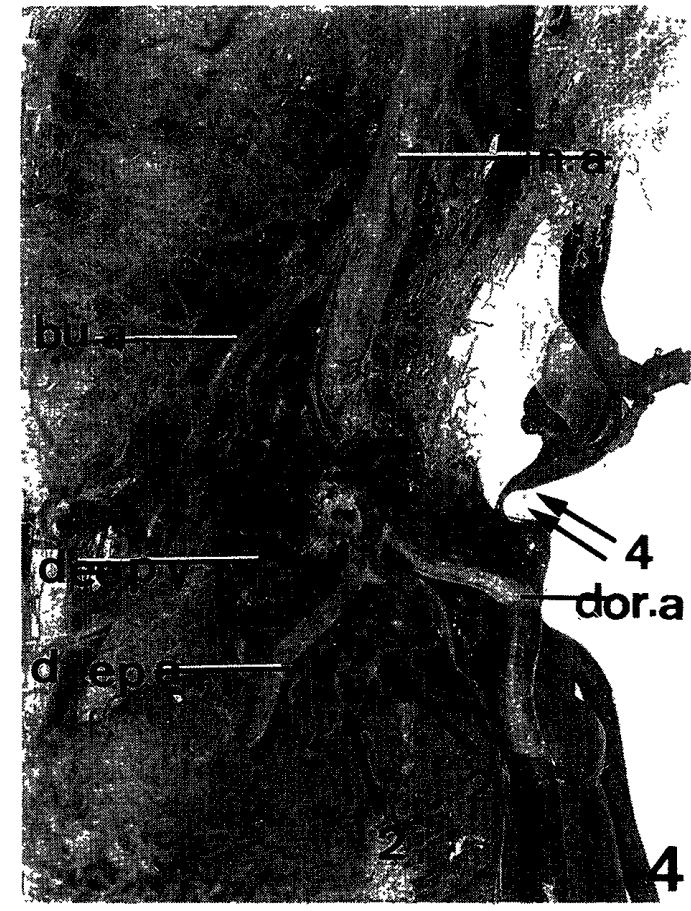

Fig. 4. Strangulation of the common trunk of the dorsal vein of the penis by the ischiourethralis muscle (double arrow 4) and extraordinally small exits, sluice channels, of the deep vein of the penis (deep. v. black arrow 2). bu. a; artery of the bulb. deep. a; deep artery of the penis. in. a; internal pudendal artery (lateral view). $\times 4.0$.

which drained blood direcrtly into the cavernous spaces. At the sites just before entering the cavernous spaces, these arterioles were histologically characterized by the remarkable cushions which projected into the small, stellate lumen (Fig. 8). These cushions were made up of epithelioid cells, irregularly disposed with muscle cells. The arteriovenous anastomoses as Conti [7] and Newman et al. [17] suggested were not observed at the arterioles just before entering the cavernous spaces.

The deep artery of the penis was also divided into 2 branches shortly after its origin. One branch ran distally to enter the proximal end of the body of the CCP and the other ran proximally to enter the crus. These main branches also ramified into many arterioles and drained blood directly into the cavernous spaces. These arterioles

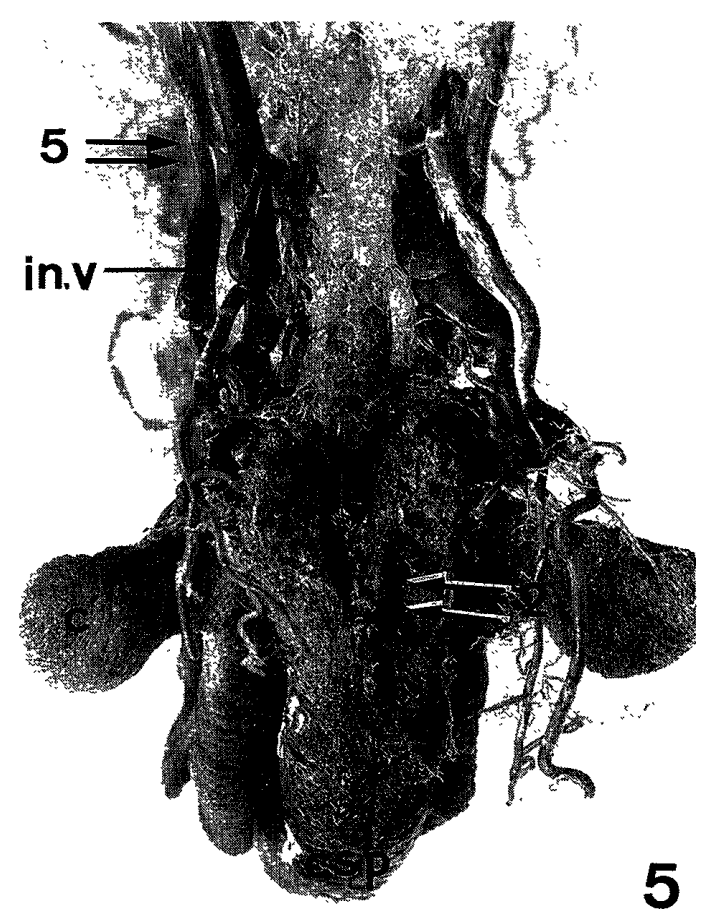

Fig. 5. The internal pudendal vein (in. v) with a narrow diameter and with a figure of compression by the levator ani, the coccygeus, and the internal obturator muscles (double arrow $5)$. (posterior view). $\times 1.0$.

also had a thickening of epithelioid cells as in the artery of the bulb. A shunt of arterial blood to the cavernous spaces as Conti [7] described in man was not found in these arterioles in the dog. In no case were the deep artery and the vein of the penis collapsed by the contraction of the IC muscle (Fig. 4), as proposed by Purohit and Beckett [22].

The dorsal artery of the penis trifurcated into the superficial, deep, and preputial branches. The superficial branch crept into the skin covering the glans and the venules from the skin merged in the cavernous spaces of the glans. The deep branch passed through the $\mathrm{BG}$ and ran along the dorsolateral side of the penile bone. In its course, it gave off numerous smaller branches to the areolar tissue surrounding the penile bone, and ramified into capillaries. The capillaries merged in small veins which ran proximally along the corresponding arteries, and drained blood into the spaces of the BG. 


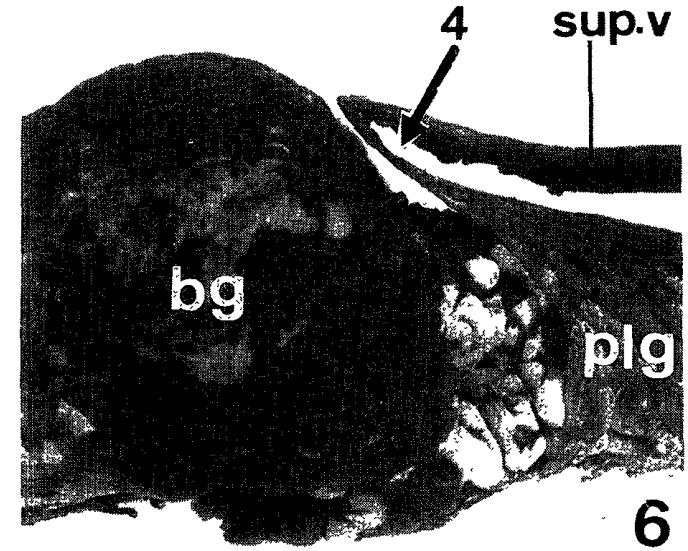

Fig. 6. The superficial vein of the glans (sup. v) with a narrow exit, representing a sluice channel (black arrow 4). (lateral view). $\times 1.5$.

Interestingly, the deep branch supplied small branches to the cavernous tissue, $i$. $e$. trabeculae of the glans. These small branches entered the tissue from the inside of the glans and ran along the trabeculae.

Veins: The drainage channels of the dog penis were the internal pudendal and the external pudendal veins. The internal pudendal vein drained blood from the dorsal vein of the penis, the deep vein of the penis, and the vein of the bulb. The internal pudendal vein, sandwiched between the levator ani, the coccygeus, and the internal obturator muscles, was compressed by the contraction of these muscles (Fig. 5). The external pudendal vein drained blood from the superficial vein of the glans. The internal and external pudendal veins had distinct valves. The deep vein of the penis and the vein of the bulb united in a common trunk before joining the internal pudendal vein. The common trunk showed an unusual characteristic feature in that it tapered toward the internal pudendal vein and showed a narrow diameter insufficient to drain blood from the penis (Fig. 7).

The deep vein drained the CCP. It originated from 5 or 6 tributaries arising from the crus before joining the vein of the bulb. It showed a significantly narrowed appearance

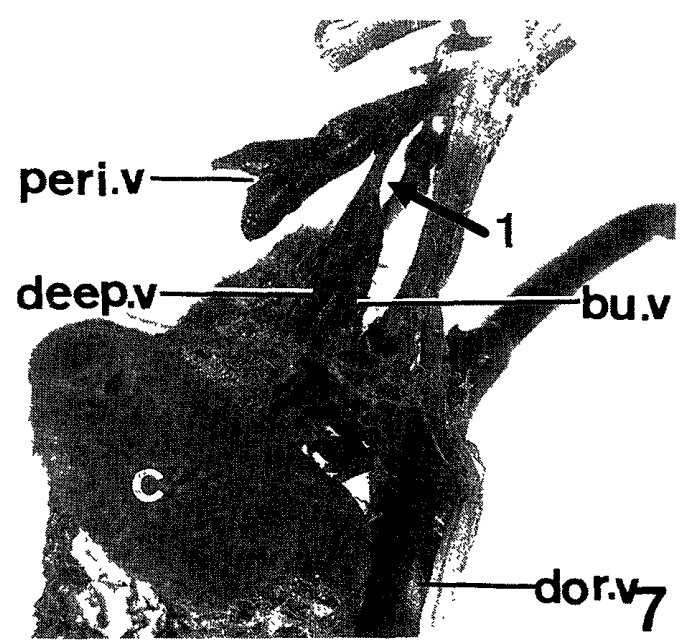

Fig. 7. The common trunk of the deep vein of the penis (deep v.) and the vein of the bulb (bu. v). Note an extremely narrow diameter forming a sluice (black arrow 1). peri. v; perineal vein. (lateral view). $\times 1.5$.

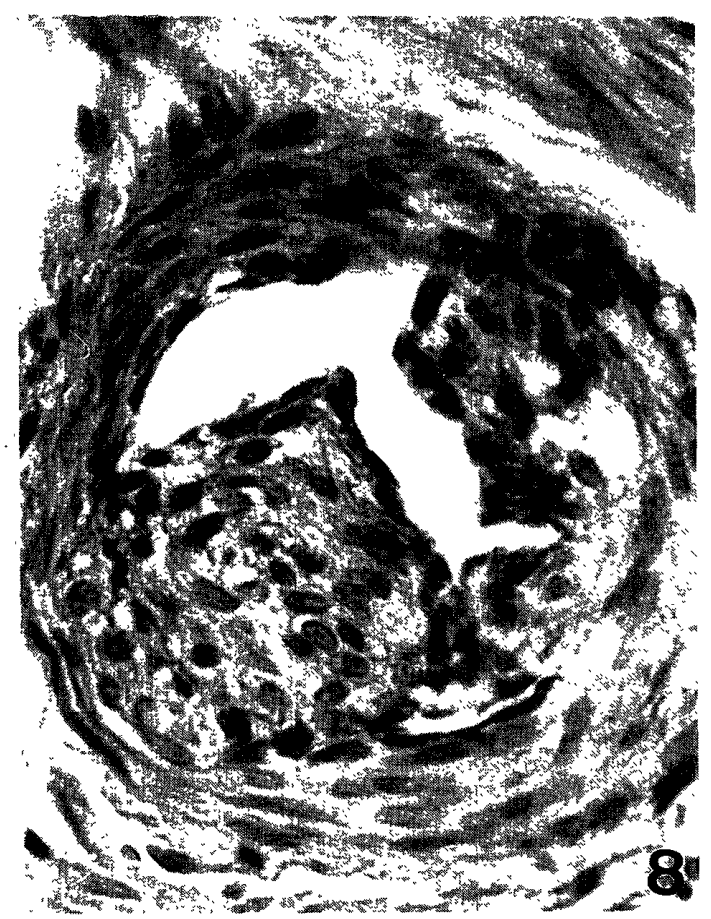

Fig. 8. Photomicrograph of a cushion arteriole in the corpus spongiosum penis. The epithelioid thickenings form a slit-shaped lumen. Hematoxylin and eosin (H. E) stain. $\times 400$.

at its emergence from the cavernous body, forming a "sluice channel" (Fig. 4). Histologically, it also showed a tapering lumen as observed in the resin casts (Fig. 9). The lumen increased in diameter as the vein 


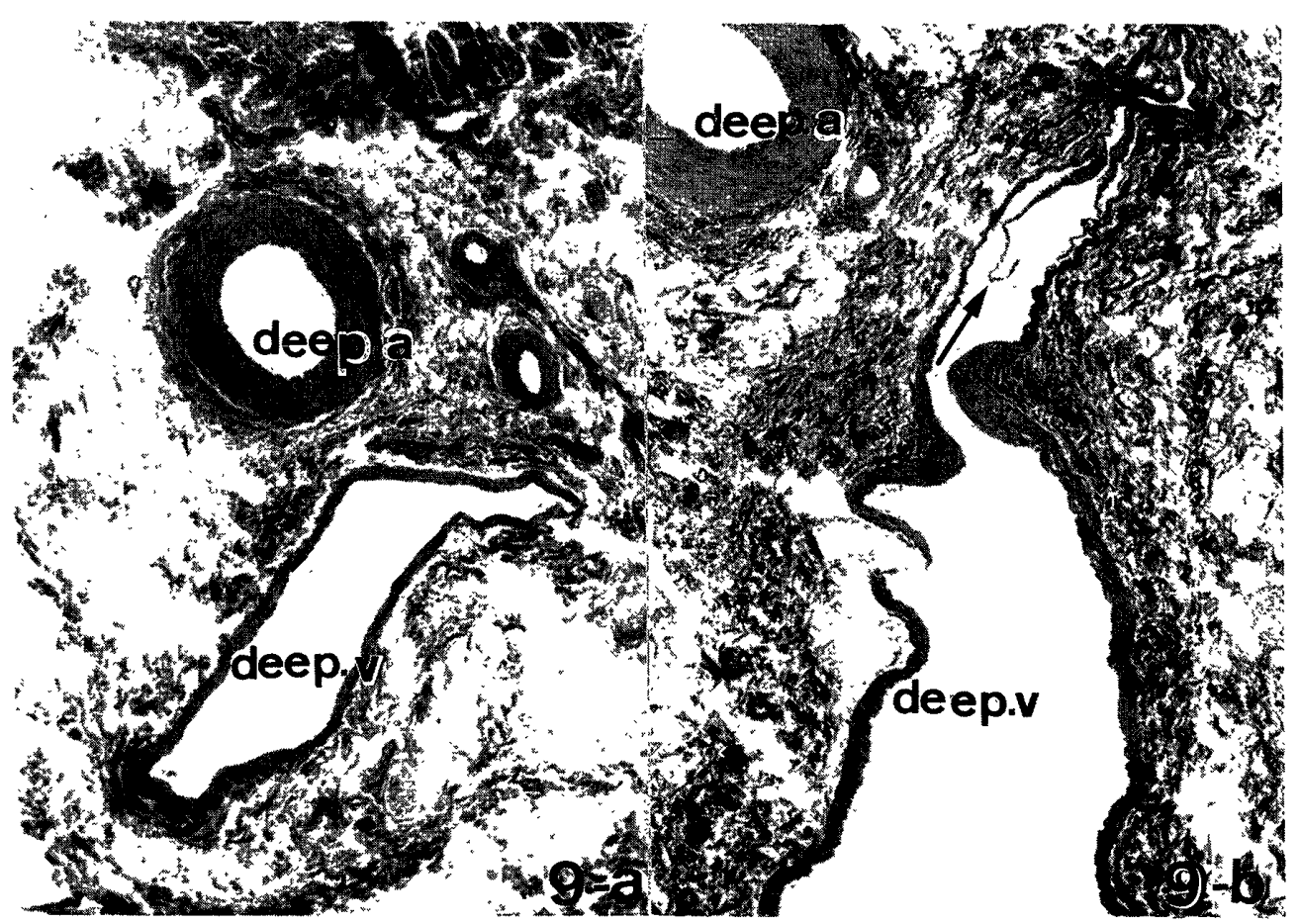

Fig. 9. Photomicrographs of the deep vein of the penis (deep. v). H. E stain. $\times 40$. a. The distal segment with narrow lumen near the emergence from the cavernous body. $b$. The Proximal segment with wider lumen. Arrow shows a venous valve.

emerged from the cavernous body.

The vein of the bulb, which drained blood from the CSP, originated from several tributaries arising from the ventromedial portion of the bulb. It also had a conspicuously narrow emergence from the cavernous body (Fig. 2).

The paired dorsal veins of the penis, which drained blood from the $\mathrm{BG}$, ran caudad before uniting in a common trunk. The common trunk was located at the insertion of the IU muscle and was completely occluded by the contraction of the IU muscle (Fig. 4).

The superficial vein of the glans draining blood from the PLG began at the dorsoproximal portion of the PLG. It turned acutely at the preputial fornix to direct distally toward the orifice and continued to the external pudendal vein. The vein from the PLG also formed a sluice channel with a lumen which was narrowed just before the preputial fornix (Fig. 6).

\section{DISCUSSION}

Our methyl methacrylate injection technique completely reproduced the whole vasculature of the penis. With these specimens, we have confirmed the descriptions of Christensen [6], Takahata [23], and Nitschke [20] and added some vascular characteristics which would play an active role in engorging cavernous spaces.

The veins draining blood from the cavernous bodies had considerably narrow emergences. Although casting artifacts are common and often difficult to be interpreted, the narrow emergences from cavernous bodies are not artifact, since they are also shown by serial sections. These emergences would be sluice channels which facilitate the engorgement of the erectile body with an increased inflow. In the future, these penile veins must be reexamined by other methods to establish additional morphological facts. 
Although the theory that many arteriovenous anastomoses located in the cavernous tissues participate in the rapid engorgement of the tissues $[7,17]$ is attractive, the anastomoses do not seem to contribute any special role in the erection process in the dog. The present study failed to demonstrate any arteriovenous anastomoses which may facilitate the conveyance of the increased blood into the cavernous spaces. Although profuse arteriovenous anastomoses are present in the skin covering the glans $[6,19,23]$, the dorsal artery of the penis also seems to play only a limited role in the rapid engorgement, since it supplies a large majority of blood to the skin.

As in other species, many cushions of epithelioid cells are observed in the arterioles in the canine erectile bodies. In the flaccid state, these cushions appear to provide a mechanism for throttling the blood that flows into the cavernous spaces. This throttling effect would, therefore, account for the description by Bloom and Fawcett [5] of the flaccid cavernous spaces as collapsed irregular clefts containing little blood. As the blood pressure increases during the erection process, the cushions appear to be passively opened by the increased blood flow, thus allowing large volumes of blood to pass into the cavernous spaces, as Fujimoto and Takeshige [11] postulated contrary to the concept of von Ebner [10], Kiss [16], and Conti [7]. When the increased blood supply to the penis subsides after the ejaculation phase of coitus, these cushions regain their original feature and again throttle the arteriole lumens.

The contractile activities of the extrinsic penile muscles, which have been studied electromyographically $[1,2,3,4,13,22]$, are indirectly demonstrated morphologically in the present study. First of all, the IC muscle compresses the crus, as its pumping activity, in line with the description of
Purohit and Beckett [22] that this muscle is the source of energy for the high pressure of the CCP during intromission. Further, they suggested that the IC muscle contracts to collapse the deep artery and vein of the penis against the ischium in order to erect the CCP. The present study, however, does not show the collapse of these vessels to form a "closed system", but shows that the extraordinally small diameter of the deep vein of the penis at its emergence site constitutes a sluice channel. This sluice channel seems to correspond to Purohit and Beckett's closed system in the CCP. The engorgement of the CCP is likely caused by the increased blood supply to the erectile body and by the sluice effect as well as the contractile activity of the IC muscle.

The BS muscle also compresses the bulb. This feature may support the concept of Hart [13] and Purohit and Beckett [22] that this muscle is obviously a compressor of the bulb and that it plays a role in pumping blood from the bulb into more distal parts of the CSP to engorge the glans.

The EAS muscle strangulates the bulb at the insertion site. The electromyographical activities of this muscle and the levator ani muscle during ejaculation have already been reported in man [21]. It is conceivable that the strangulating activity of the EAS muscle prevents blood in the CSP from going back to the bulb when the BS muscle relaxes to allow blood to flow into the bulb during the pumping action of the muscle.

The IU muscle contracts to occlude the common trunk of the dorsal vein of the penis. This observation supports the description of Christensen [6] and Hart [14] that the IU muscle contracts to facilitate erection of the glans by occluding venous return.

The compression of the internal pudendal vein by the contraction of the levator ani, the coccygeus, and the internal obturator muscles indicates that these muscles play an 
active role in slowing blood egress from the engorged copulative organ.

\section{REFERENCES}

1. Beckett, S. D., Hudson, R. S., Walker, D. F., Vachon, R. I., and Reynolds, T. M. 1972. Corpus cavernosum penis pressure and external penile muscle activity during erection in the goat. Biol. Reprod. 7: 359-364.

2. Beckett, S. D., Hudson, R. S., Waker, D. F., Reynolds, T. M., and Vachon, R. I. 1973. Blood pressures and penile muscle activity in the stallion during coitus. Am. J. Physiol. 225: 1072-1075.

3. Beckett, S. D., Donald, F. W., Hudoson, R. S., Reynolds, T. M., and Vachon, R. I. 1974. Corpus cavernosum penis pressure and penile muscle activity in the bull during coitus. Am. J. Vet. Res. 35: 761-764.

4. Beckett, S. D., Walker, D. F., Hudson, R. S., Reynolds, T. M., and Purohit, R. C. 1974. Corpus spongiosum penis pressure and penile muscle activity in the stallion during coitus. Am. J. Vet. Res. 36: 431-433.

5. Bloom, W. and Fawcett, D. W. 1978. The penis. pp. 851-855. In: Textbook of Histology. 10th ed. (Asian ed.), Saunders, Philadelphia,

6. Christensen, G. C. 1954. Angioarchitecture of the canine penis and the process of erection. Am. J. Anat. 95: 227-261.

7. Conti, C. 1952. L' erection du penis humain et ses bases morphologico-vasculares. Acta. Anat. 14: 217-262.

8. Deysach, L. J. 1939. The comparative morphology of the erectile tissue of the penis with especial emphasis on the probable mechanism of erection. Am. J. Anat. 64: 111-131.

9. Dorr, L. D. and Brody M. J. 1969. Hemodynamic mechanisms of erection in the canine penis. Am. J. Physiol. 213: 1527-1531.

10. von Ebner V. 1900. Uber klappenartige Vorsichtungen in den Arterien der Schwellkorper. Anat. Anz, 18: 79-81.

11. Fujimoto S. and Takeshige Y. 1974. The wall structure of the arteries in the corpora cavernosa penis of rabbits; Light and electron microscopy. Anat. Rec. 181: 641-658.

12. Grandage J. 1972. The erect dog penis: A paradox of flexible rigidity. Vet. Rec. 5: 141-147.

13. Hart, B. L. 1966. Penile erection and contraction of penile muscles in the spinal and intact dog. Am. J. Physiol. 210: 257-262.

14. Hart, B. L. 1972. The action of extrinsic penis muscles during copulation in the male dog. Anat. Rec. 173: 1-5.

15. Henderson, V. E. and Roepke M. H. 1933. On the mechanism of erection. Am. J. Physiol. 106: 441-448.

16. Kiss, F. 1921. Anatomisch-histologishe Untersuchungen uber die Erection. Z. Anat. 61: 455-521.

17. New man, F. F., Northup, J. D., and Devlin, J. 1964. Mechanism of human penil erection. Invest. Urol. 1: 350-353.

18. Ninomiya, H. 1980. The penile cavernous system and its morphological changes in the erected state in the dog. Jpn. J. Vet. Sci. 42: 187-195.

19. Ninomiya, H. and Nakamura, T. 1981. The capillary circulation in the penile skin of the dog. Zbl. Vet. Med. C. Anat. Histol. Embryol. 10: 361-369.

20. Nitschke, T. 1965. Zur Frage der Vena profunda glandis des Ruden. Anat. Anz. 118: 474-476.

21. Petersen, E. and Stener, I. 1970. An electromyographical study of the striated urethral sphincter, the striated anal sphincter, and the levator ani muscle during ejaculation. Electromyogr. 1: 23-44.

22. Purohit, R. C. and Beckett, S. D. 1976. Penile pressure and muscle activity associated with erection and ejaculation in the dog. Am. J. Physiol. 231: 1343-1348.

23. Takahata, K., Kudo, N., Furuhata, K., Sugimura, M., and Tamura, T. 1962. Fine angioarchitectures in the penis of the dog. Jpn. J. Vet. Res. 10: 203-220.

24. Vaerst, L. 1938. Uber die Blutversorgung des Hundepenis. Gegenbauers Morphol. Jahrb. 81: 307-352. 
要

約

イヌの陰茥の血管系：樹脂鋳型法による観察：二宮博義・中村経紀・新妻勲夫 ${ }^{1)}$ ・土屋新男 ${ }^{2}$ (麻布大学獣医 学部実験動物学教室, 2)環境保健学部環境病理学教室, 1)開業)——イヌの陰茥の血管系をアクリル樹脂鋳型法で 立体的に観察した。さらに，鋳型標本で特微的な部位について，連続切片により組織学的観察も行った. 注入樹 脂の刺激作用により，坐骨海綿体筋と球海綿体筋が収縮し，陰茥脚と尿道球が圧縮されており，これらの筋が勃 起時に海綿体内压を維持するためのポンプ効果を持つことが示唆された．さらに，尿道球の遠部位が外肛門括約 筋の圧縮を受けており，尿道海綿体中の血液が尿道球へ逆流しないように作用することが示唆された。陰茎背静 脈も坐骨尿道笳により王迫され狭窑していた。陰菱背静脈と尿道球静脈を集める内陰部静脈も肛門挙筋，尾骨筋 および内閉鎖笳により压迫され狭䇤していた。また，陰茎深静脈，尿道球静脈および浅亀頭静脈が海綿体から出 る部分は極端に細く，“堰 sluice channel”を構成していた。こうした筋の収縮作用や排出静脈の堰構造は，陰茥 勃起時の海綿体洞への血液充満に重要な働きをするものと考えられた。 